
Kidney
Blood Pressure
Research

Kidney Blood Press Res 2015;40:306-314

Review

\title{
The Missing Link - Likely Pathogenetic Role of GM3 and Other Gangliosides in the Development of Diabetic Nephropathy
}

\author{
Igor Vukovic Josko Bozic Anita Markotic Srecko Ljubicic Tina Ticinovic Kurir \\ Department of Pathophysiology, University of Split, School of Medicine, Split, Croatia
}

\section{Key Words}

Ganglioside $\cdot$ GM3 $•$ Diabetic nephropathy $\bullet$ Lipid rafts

\begin{abstract}
Despite scientific advances, diabetic nephropathy remains both a therapeutical challenge, and one of the major diabetic complications. Chemical structure of gangliosides, the most complex of glycosphingolipids, is characterised by one or more sialic acids and carbohydrate groups linked to a ceramide structure. Their potential pathogenetic role in a number of disorders linked to diabetes mellitus has recently been conjectured, due to evidence of their negative modulation of the insulin-mediated signaling and general effects on key cell functions like proliferation, differentiation, apoptosis, cellular signaling and adhesion. Elevated levels of advanced glycation products (AGE) usually found in diabetic conditions seem to be responsible for increased concentration of a-series gangliosides in tissues, most notably GM3. GM3 was shown to compromise the renal pericyte and mesangial cell regeneration via the inactivation of VEGF receptor and the receptor-associated Akt signaling pathway. Likewise, the lipid raft theory opened a new research area for GM3 influence, since in the glycosynapse model glycosphingolipids have a key cell-to-cell communication unit with modulating capabilities on signaling receptors. The goal of this review is to provide insight into currently available theories on proposed mechanisms that mark the GM3 as a pathophysiological mediator in the development of diabetic nephropathy.
\end{abstract}

Copyright @ 2015 S. Karger AG, Basel

\section{Introduction}

Diabetes mellitus is a major cause of end-stage renal disease (ESRD) worldwide, in both first-world countries [1] and in developing ones [2,3]. It occurs in up to $40 \%$ of diabetic patients, somewhat more frequently in type I than in type II. Diabetic nephropathy is

I. Vukovic and J. Bozic contributed equally to this study and thus share first authorship. 


\section{Kidney Blood Pressure Research}

Kidney Blood Press Res 2015;40:306-314

\begin{tabular}{l|l}
\hline DOI: $10.1159 / 000368506$ & (C) 2015 S. Karger AG, Basel
\end{tabular}

Published online: May 30, 2015

www.karger.com/kbr

characterized by an onset of microalbuminuria coupled with increased glomerular filtration rate (GFR) in the initial stage, followed by progressive increase of the total urine protein excretion and decrease of the GFR. A fully developed nephrotic syndrome is marked by total urine protein excretion of over $3.5 \mathrm{~g} /$ day [4]. According to de Zeeuw et al., albuminuria itself is a reliable predictor of diabetic nephropathy development and various therapeutic antiproteinuric strategies are expected to be adopted [5].

Diabetic nephropathy pathogenesis remains in focus for many research groups [6-11]. It was shown in previous research that the proliferation of the extracellular matrix plays a key role in pathogenesis of diabetic nephropathy. It is most likely induced by the activity of the transforming growth factor $\beta$ (TGF- $\beta$ ). The stimulation of TGF- $\beta$ is a focal point where various mediators intercede; glucose, advanced glycation products (AGE), endothelin and angiotensin II [12]. The expansion of extracellular matrix causes thickening of glomerular basal membrane, as well as the tubulo-interstitial and mesangial compartment [13]. This mechanism is responsible for obstruction of the glomerular filtration [14]. Also, inflammatory processes, probably induced by stimulatory effects of hyperglycemia on the nuclear factor$\kappa \beta$ (NF- $\kappa \beta$ ) system and macrophages producing IL-12, contribute to glomerulo-tubular damage and further augment signaling pathways facilitating the deposition of extracellular matrix [15]. Inflammatory pathways seem to be interlinked with those of systemic and local hypertensive pathomechanisms, since angiotensin II, through the $\mathrm{AT}_{1}$ receptor, induces the protein kinase C (PKC) activity, and also rises the intracellular levels of reactive oxygen species (ROS), [16] contributing to the inflammatory process. Activation of Gq alpha subunitcoupled signaling pathways in glomerular podocytes promotes renal injury [17]. AT ${ }_{1}$ receptor is $\mathrm{G}$ protein-coupled receptor. Commonly, $\mathrm{Gq}$ alpha subunit of $\mathrm{G}$ protein-coupled receptors activates phospholipase C. Phospholipase $C$ generates DAG as second messenger of AT1 receptor binding, further activating protein kinase C. PKC induction by AT1 is synergistically affected by reactive oxygen species, generated by interactions of AGE and corresponding receptors, which also increases the phospholipase $\mathrm{C}$ activity producing more molecular units of DAG. This double pathway PKC activation defines its central role in diabetic nephropathy pathogenesis [18]. PKC is responsible for up regulation of NADPH-oxidase expression, additionally increasing ROS quantities and the intensity of the inflammatory process and for induction of the cytokine TGF- $\beta$ leading to consequential above-mentioned mechanisms [19].

At the present moment, there are no specific therapeutic modalities available for management of diabetic nephropathy. Clinicians resort to maintaining plasma glucose and triglyceride level and arterial blood pressure values within physiological ranges, while plasma urea, creatinine and albuminuria levels serve as prime indicators of disease progression.

Among etiologic factors assumed to be involved in the pathological cause-effect cascade that links hyperglycemia with kidney damage leading to diabetic nephropathy are gangliosides, most notably GM3 [20]. There is a scarce of data concerning relation of PKC activity and GM3 levels. GM3 synthase gene is expressed by PKC activation in human leukemia cells [21]. The goal of this review is to provide insight into currently available theories on proposed mechanisms that mark the GM3 as a pathophysiological mediator in the development of diabetic nephropathy. We focused our interest in early reversible phase of diabetic nephropathy (hyperfiltration and microalbuminuria) and the advanced stage of diabetic nephropathy would not be refered to in this manuscript.

\section{Biochemical structure and functional roles of gangliosides}

Gangliosides are the most complex glycosphingolipids. Etymologically, their name reflects the fact that they are mostly present in plasma membranes of neural cells. By their chemical structure, they are characterized by the presence of one or more sialic acids 


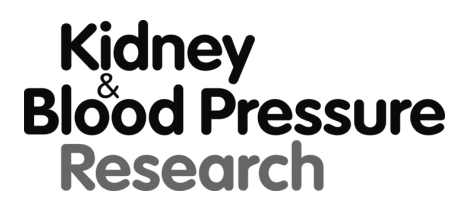

Kidney Blood Press Res 2015;40:306-314

\begin{tabular}{l|l}
\hline DOI: $10.1159 / 000368506$ & (c) 2015 S. Karger AG, Basel
\end{tabular}

Published online: May 30, 2015

www.karger.com/kbr

308

Vukovic/Bozic/Markotic/Ljubicic/ Ticinovic Kurir: GM3 and Diabetic Nephropathy

and carbohydrate groups linked on the ceramide molecular structure. Gangliosides are categorized according to the Svennerholm classification. Letters "M, D, T, Q" and "P" indicate the number of sialic acid groups on molecules $(M=1 \ldots P=5)$. Numbers " $1-4$ " designate the number of carbohydrate groups bound to ceramide, derived from the formula; $n=5$ number of carbohydrate groups. When present, lowercase letters " $a$ ", " $b$ " and "c" indicate the number of sialic acids on the inner galactose segment [22]. Therefore, the eponymous GM3 ganglioside contains a single sialic group with 2 carbohydrate groups bound to a ceramide structure. GM3 formation is catalyzed by the GM3 synthase, a lactosylceramide $\alpha 2,3$ - sialyl transferase, that catalyses the N-acetylneuraminic (sialic) acid transfer on the terminal galactose residue of lactosylceramide [23]. Glycosyltransferases are enzymes that catalyse ganglioside synthesis and determine the key sequence of carbohydrates in the glycosphingolipid chain [24].

GM3 ganglioside is linked with a variety of physiological functions on the molecular level, such as: control of cell proliferation and differentiation, apoptosis, cellular signaling pathways, cell adhesion and mobility [25-28]. It is ubiquitous in almost all organ systems. Highest levels are found in the cerebral cortex, liver, spleen, placenta, thyroid gland, kidneys and skeletal muscles. Thin-layer chromatography (TLC) colorimetric analysis defined the GM3 a dominant ganglioside in kidney tissue, where it comprises three quarters of total gangliosides present in the kidney [29]. Significant body of evidence emphasizes negative modulation effects of GM3 on insulin-mediated signaling pathways, at the same time highlighting its potential role in the development of type II diabetes [30, 31].

Another important nephrologic clinical syndrome has also been linked with GM3 as an underlying cause, namely the polycystic kidney disease (PKD) and more notably the nephronophthisis related-PKD. According to Natoli et al., GM3 and GM3 precursor, glucosylceramide (GlcCer) seem to promote cystogenic activity [32]. Loss of the GM3 synthase gene was reported to have a protective effect on forming cystic structures in rats, while authors highlighted the inhibitory effects of GM3 on cell cycle induction and Akt/ mTOR signaling pathway, a pathway linked with cystogenic effects. They also hypothesized the potential GM3 interference with EGF and IGF-1 signal receptors on lipid rafts, which are both cystogenic mediators [32].

\section{GM3 interferes with regenerative capacity of renal cells}

AGE are a key biochemical characteristic of diabetes [33]. In a concentration-dependent reaction, surplus sugar molecules bind to protein structures without the mediation of enzymes, causing conformational changes and protein function disruptions. Masson et al., reported a positive correlation between the increase in AGE levels and increased levels of a-series gangliosides in rat renal mesangial cells, with GM3, GM2 and GM1 particularly increased [34]. The effective increase in ganglioside concentrations is coupled by a significant up-regulation of expression of ganglioside synthases responsible for production of respective gangliosides and also by an inhibition of synthase enzymes, that mediate the production of GM3-derived molecules. GM3 levels are subsequently further increased by blocking its usage as a precursor for other ganglioside types. Because of their given influence on cell proliferation, gangliosides are proposed to be a factor responsible for proliferatory inhibition of pericyte and mesangial renal cells [35], particularly through the possible inhibition of vascular endothelial growth factor (VEGF) effects as was proved by addition of GM3 in cell culture [36]. In addition, GM3 in lipid rafts on the surface of human podocytes binds soluble vascular endothelial growth factor receptor FLT1, one of the key regulators of angiogenesis, promoting adhesion and rapid actin reorganization [37].

The in vitro studies focusing on renal mesangial cells reveal that Akt signaling pathway, activated by phosphatidylinositol-4,5-bisphosphate 3-kinase in the presence of platelet- 


\section{Kidney Blood Pressure Research}

derived growth factor (PDGF), attributes significantly to regenerative processes, due to its blockage of apoptotic induction through the activation of NF- $\mathrm{KB}$ and the phosphorylation of Bad pathways [38]. This proposed model emphasizes ganglioside role in compromising the kidney vascular endothelium cell regeneration processes.

\section{Lipid raft model of GM3 influence}

The connection between increased GM3 levels and several diabetic complications is established $[39,40]$. The missing link between the abovementioned phenomenon and the diabetic nephropathy could lie in the concept of the so-called "lipid rafts“. Ever since Singer and Nicholson proposed the revolutionary mosaic double-layer model of the cellular membrane structure, numbers of publications and body of knowledge have expanded in an exponential trend [41-43]. Following the evolution of basic biomedical sciences, the physiological and clinical focus in disease research migrated to the molecular level, and diabetology research proved no exception. Among the newer concepts that attempt to contribute to the general understanding of insulin physiology and pathophysiology are caveolae and lipid raft membrane formations. Simons and Ikonen presented a model in which sphyngolipids and cholesterol form mobile clusters on the lipid double layer [44]. Caveolae are defined as invaginations $50-100 \mathrm{~nm}$ in diameter, placed in cell membranes and formed by special proteins; caveolins (present in three isomeres) [45]. Caveolae are rich in lipid raft structures, and serve as placement sites for various receptors, with possible important roles in signal transduction [46]. In the proposed glycosynapse model, glycosphingolipids form cluster formations that have a functional role in cell-to-cell communication, play a part in cellular adhesion systems or modulate certain receptor functions, therefore affecting signal transduction as well [47-49].

In a study of renal Na+-glucose cotransporter type 2 (SGLT2) expression and activity in streptozotocin induced diabetic rats, conducted by Albertoni-Borghese et al., authors concluded that altered SGLT2 activity could be a consequence of changes in membrane lipid composition (decrease in sphingomyelin content and an increase in phosphatidylcholine) [50]. Also, published results suggest that the renal $\mathrm{Na}^{+} / \mathrm{K}^{+} / \mathrm{Cl}^{-}$ cotransporter is lipid raft-dependent [51]. This physiological process causes increased tubular reabsorption with higher hydrostatic pressures in efferent arterioles. It is presumed that such an effect would remodulate the tubuloglomerular balance of the "Guytonian" kidney increasing the glomerular filtration rate and hydrostatic tubular pressure, eventually damaging the tubular cell system in a manner presented in Figure 1. GM3 is the most abundant renal ganglioside and together with ganglioside GM1 constitute lipid rafts [52]. GM3 rafts are localized predominantly on the peaks of microvillus-like protrusions in the apical membrane of canine kidney cells, whereas GM1 rafts are distributed mainly on the slops of protrusions or the valleys between protrusions in the plasma membranes [53]. However, due to missing data on direct GM3 influence upon renal SGLT2 and $\mathrm{Na}^{+} / \mathrm{K}^{+} / \mathrm{Cl}^{-}$cotransporters, VEGF and Akt signaling pathways remain more likely GM3 targets leading to depletion of functional renal parenchyma (Figure 1).

\section{Maintaining the glomerulo-tubular barrier polarity; an alternate point of view}

An interesting and considerably different approach was proposed by Kwak et al. They reported of lowered total ganglioside concentrations in kidney glomerulus in diabetic conditions, with streptozotocin-induced diabetic rats [54]. Among the pathogenetic mechanisms they proposed is the concept in which gangliosides contribute to the total amount of membrane negative electric charge [55]. In renal physiology, the electronegative groups situated on the glomerular basement membrane have a key function in restricting the filtration to 


\section{Kidney Blood Pressure Research}

a balanced amount, since the plasma proteins carry electronegative charges from acid groups and are repelled by the glomerular charges of the same polarity, preventing proteinuria and polyuria that would appear due to changes in the glomerulo-tubular oncotic balance [56, 57]. The mentioned results showed that total ganglioside levels decrease during diabetic conditions. Authors presume that consequently the glomerular filtration becomes less selective and permits increased quantity of charged ions to pass through glomerular barrier. The hydrostatic pressure would be increased due to a shift in osmotic and oncotic balance, eventually causing damage to the tubular cells, due to their exposure to increased pressure and mechanical stress.

In addition to gangliosides, negative electric charge of glomerulus belongs to heparan sulfate proteoglycans, constituents of glomerular basement membrane (GBM) [58]. High glucose level inhibits activity of key enzyme of heparan sulfate synthesis (N-deacetylase: $\mathrm{N}$-sulfotransferase) contributing to the loss of electronegative charge and increased permeability of glomerulus [59].The glomerulus capillaries are lined by fenestrated endothelial cells and covered by specialized epithelial cells known as podocytes. GBM is between the endothelial and podocyte cell layers [60]. Among three layfinal consequence of depletion of functional renal parenchyma.
Fig. 1. Proposed mechanisms how hyperglycemia lead to GM3 increase with 


\section{Kidney \\ Blood Pressure Research}

ers of glomerulus, podocyte is now regarded as an important component for controlling the glomerular permeability [61]. Podocyte is adhered to GBM by integrin which is contained in lipid raft [62]. Podocyte detachment from GBM was reported in type1 diabetic nephropathy [63]. Gain of glycosylation in integrin $\alpha 3$ causes nephrotic syndrome [64]. Deletion of vascular endothelial growth factor receptor FLT1 from podocytes, causes reorganization of their cytoskeleton with massive proteinuria and kidney failure, characteristic features of nephrotic syndrome in humans [37]. Knowing that GM3 in lipid rafts on the surface of human podocytes binds soluble vascular endothelial growth factor receptor FLT1 resulting in correct structure of podocyte slit diaphragm that prevents proteinuria [37], we can assume that loss of GM3 will result with nephrotic syndrome too.

\section{Conclusion}

Although diabetic nephropathy has been recognized as a major diabetic complication for quite some time, the exact pathogenesis remains terra incognita in need of further scientific research. The implications of the proposed model, in which gangliosides are the key pathophysiological mediator, introduce novel molecular interaction pathways that take part in the course of the disease. Since gangliosides are considered to be an important and widespread cellular signal modulators, the totality of their interactions in cellular functions and cell cycle, and therefore also in the titular pathological entity of this paper are numerous and currently difficult to predict. Apart from disorders on the molecular scale, tubular damage from increased luminal hydrostatic pressure is proposed as an important factor. The whole picture of diabetic nephropathy, comparable to the lipid raft model, is in fact a mosaic of various single molecular discoveries, giving possibility to different insights and approaches when dealing with pathogenetic mechanisms in new research. As rafts float on the ocean of a lipid double layer, so does our current knowledge on diabetic nephropathy on the surface of physiology, open to ideas from various domains of thought.

\section{Disclosure Statement}

The authors of this manuscript state that they do not have any conflict of interests and nothing to disclose.

\section{References}

1 Tumlin JA, Galphin CM, Rovin BH: Advanced Diabetic Nephropathy with Nephrotic Range Proteinuria: A Pilot Study of the Long-Term Efficacy of Subcutaneous ACTH Gel on Proteinuria, Progression of CKD, and Urinary Levels of VEGF and MCP-1. J Diabetes Res 2013;2013:489869.

2 Zhuo L, Zou G, Li W, Lu J, Ren W: Prevalence of diabetic nephropathy complicating non-diabetic renal disease among Chinese patients with type 2 diabetes mellitus. Eur J Med Res 2013;18:4.

3 Choukem SP, Dzudie A, Dehayem M, Halle MP, Doualla MS, Luma H, Kengne AP: Comparison of different blood pressure indices for the prediction of prevalent diabetic nephropathy in a sub-Saharan African population with type 2 diabetes. Pan Afr Med J 2012;11:67.

4 Stoycheff N, Stevens LA, Schmid CH, Tighiouart H, Lewis J, Atkins RC, Levey AS: Nephrotic syndrome in diabetic kidney disease: an evaluation and update of the definition. Am J Kidney Dis 2009;54:840-849.

5 de Zeeuw D, Remuzzi G, Parving HH, Keane WF, Zhang Z, Shahinfar S, Snapinn S, Cooper ME, Mitch WE, Brenner BM: Albuminuria, a therapeutic target for cardiovascular protection in type 2 diabetic patients with nephropathy. Circulation 2004;110:921-927. 


\section{Kidney \\ Blood Pressure Research}

Kidney Blood Press Res 2015;40:306-314

\begin{tabular}{l|l}
\hline DOI: 10.1159/000368506 & C 2015 S. Karger AG, Basel
\end{tabular}

Published online: May 30, 2015

www.karger.com $/ \mathrm{kbr}$

Vukovic/Bozic/Markotic/Ljubicic/ Ticinovic Kurir: GM3 and Diabetic Nephropathy

6 Alter ML, Ott IM, von Websky K, Tsuprykov O, Sharkovska Y, Krause-Relle K, Raila J, Henze A, Klein T, Hocher B: DPP-4 Inhibition on top of angiotensin receptor blockade offers a new therapeutic approach for diabetic nephropathy. Kidney Blood Press Res 2012;36:119-130.

7 Tufro A: Cholesterol accumulation in podocytes: a potential novel targetable pathway in diabetic nephropathy. Diabetes 2013;62:3661-3662.

8 Mise K, Hoshino J, Ubara Y, Sumida K, Hiramatsu R, Hasegawa E, Yamanouchi M, Hayami N, Suwabe T, Sawa N, Fujii T, Ohashi K, Hara S, Takaichi K: Renal prognosis a long time after renal biopsy on patients with diabetic nephropathy. Nephrol Dial Transplant 2014;29:109-118.

9 Kuricová K, Tanhäuserová V, Pácal L, Bartáková V, Brožová L, Jarkovský J, Kaňková K: NOS3 894G>T polymorphism is associated with progression of kidney disease and cardiovascular morbidity in type 2 diabetic patients: NOS3 as a modifier gene for diabetic nephropathy? Kidney Blood Press Res 2013;38:9298.

10 Železníková V, Vedralová M, Kotrbová-Kozak A, Zoubková H, Černá M, Rychlík I: The intron 4 polymorphism in the calcium-sensing receptor gene in diabetes mellitus and its chronic complications, diabetic nephropathy and non-diabetic renal disease. Kidney Blood Press Res 2014;39:399-407.

11 Eren Z, Günal MY, Bakir EA, Coban J, Çağlayan B, Ekimci N, Ethemoglu S, Albayrak O, Akdeniz T, Demirel GY, Kiliç E, Kantarci G: Effects of paricalcitol and aliskiren combination therapy on experimental diabetic nephropathy model in rats. Kidney Blood Press Res 2014;39:581-590.

12 Cooper ME: Pathogenesis, prevention, and treatment of diabetic nephropathy. Lancet 1998;352:213-219.

13 Kanwar YS, Sun L, Xie P, Liu FY, Chen S: A glimpse of various pathogenetic mechanisms of diabetic nephropathy. Annu Rev Pathol 2011;6:395-423.

14 Mason RM, Wahab NA: Extracellular matrix metabolism in diabetic nephropathy. J Am Soc Nephrol 2003;14:1358-1373.

15 Mima A: Inflammation and oxidative stress in diabetic nephropathy: new insights on its inhibition as new therapeutic targets. J Diabetes Res 2013;2013:248563.

16 Higuchi S, Ohtsu H, Suzuki H, Shirai H, Frank GD, Eguchi S: Angiotensin II signal transduction through the AT1 receptor: novel insights into mechanisms and pathophysiology. Clin Sci (Lond) 2007;112:417-428.

17 Wang L, Fields TA, Pazmino K, Dai Q, Burchette JL, Howell DN, Coffman TM, Spurney RF: Activation of Galpha q-coupled signaling pathways in glomerular podocytes promotes renal injury. J Am Soc Nephrol 2005;16:3611-3622.

18 Inoguchi T, Sonta T, Tsubouchi H, Etoh T, Kakimoto M, Sonoda N, Sato N,Sekiguchi N, Kobayashi K, Sumimoto $\mathrm{H}$, Utsumi H, Nawata H: Protein kinase C-dependent increase in reactive oxygen species (ROS) production in vascular tissues of diabetes: role of vascular NAD(P)H oxidase. J Am Soc Nephrol 2003;14:S227-S232.

19 Kanwar YS, Wada J, Sun L, Xie P, Wallner EI, Chen S, Chugh S, Danesh FR: Diabetic nephropathy: mechanisms of renal disease progression. Exp Biol Med (Maywood) 2008;233:4-11.

20 Fox TE, Kester M: Therapeutic strategies for diabetes and complications: a role for sphingolipids? Adv Exp Med Biol 2010;688:206-216.

21 Choi HJ, Park YG, Kim CH: Lactosylceramide alpha2,3-sialyltransferase is induced via a PKC/ERK/CREBdependent pathway in K562 human leukemia cells. Mol Cells 2007;23:138-144.

22 Svennerholm L: Chromatographic separation of human brain gangliosides. J Neurochem 1963;10:613-623.

23 Martínez MA, López S, Arias CF, Isa P: Gangliosides have a functional role during rotavirus cell entry. J Virol 2013;87:1115-1122.

24 Iber H, Kaufmann R, Pohlentz G, Schwarzmann G, Sandhoff K: Identity of GA1, GM1a and GD1b synthase in Golgi vesicles from rat liver. FEBS Lett 1989;248:18-22.

25 Uemura S, Feng F, Kume M, Yamada K, Kabayama K, Nishimura S, Igarashi Y, Inokuchi J: Cell growth arrest by sialic acid clusters in ganglioside GM3 mimetic polymers. Glycobiology 2007;17:568-577.

26 Alessandri G, Cornaglia-Ferraris P, Gullino PM: Angiogenic and angiostatic microenvironment in tumors-role of gangliosides. Acta Oncol 1997;36:383-387.

27 Sohn H, Kim YS, Kim HT, Kim CH, Cho EW, Kang HY, Kim NS, Kim CH, Ryu SE, Lee JH, Ko JH: Ganglioside GM3 is involved in neuronal cell death. FASEB J 2006;20:1248-1250.

28 Nakamura M, Kirito K, Yamanoi J, Wainai T, Nojiri H, Saito M: Ganglioside GM3 can induce megakaryocytoid differentiation of human leukemia cell line K562 cells. Cancer Res 1991;51:1940-1945. 


\section{Kidney \\ Blood Pressure Research}

Kidney Blood Press Res 2015;40:306-314

\begin{tabular}{l|l}
\hline DOI: 10.1159/000368506 & C 2015 S. Karger AG, Basel
\end{tabular}

Published online: May 30, 2015

www.karger.com $/ \mathrm{kbr}$

Vukovic/Bozic/Markotic/Ljubicic/ Ticinovic Kurir: GM3 and Diabetic Nephropathy

29 Prokazova NV, Samovilova NN, Gracheva EV, Golovanova NK: Ganglioside GM3 and its biological functions. Biochemistry (Mosc) 2009;74:235-249.

30 Yamashita T, Hashiramoto A, Haluzik M, Mizukami H, Beck S, Norton A, Kono M, Tsuji S, Daniotti JL, Werth N, Sandhoff R, Sandhoff K, Proia RL: Enhanced insulin sensitivity in mice lacking ganglioside GM3. Proc Natl Acad Sci USA 2003;100:3445-3449.

31 Tagami S, Inokuchi Ji J, Kabayama K, Yoshimura H, Kitamura F, Uemura S, Ogawa C, Ishii A, Saito M, Ohtsuka Y, Sakaue S, Igarashi Y: Ganglioside GM3 participates in the pathological conditions of insulin resistance. J Biol Chem 2002;277:3085-3092.

32 Natoli TA, Husson H, Rogers KA, Smith LA, Wang B, Budman Y, Bukanov NO, Ledbetter SR, Klinger KW, Leonard JP, Ibraghimov-Beskrovnaya O: Loss of GM3 synthase gene, but not sphingosine kinase 1, is protective against murine nephronophthisis-related polycystic kidney disease. Hum Mol Genet 2012;21:3397-3407.

33 Stróżecki P, Kurowski R, Flisiński M, Stefańska A, Odrowąż-Sypniewska G, Manitius J: Advanced glycation end products and arterial stiffness in diabetic and non-diabetic patients with chronic kidney disease. Pol Arch Med Wewn 2013;123:609- 616.

34 Masson E, Troncy L, Ruggiero D, Wiernsperger N, Lagarde M, El Bawab S: a-series gangliosides mediate the effects of advanced glycation end products on pericyte and mesangial cell proliferation: a common mediator for retinal and renal microangiopathy? Diabetes 2005;54:220-227.

35 Tsuboi N, Utsunomiya Y, Kawamura T, Kawano T, Hosoya T, Ohno T, Yamada H: Ganglioside as an endogenous growth suppressor for glomerular mesangial cells. Kidney Int 2001;60:1378-1385.

36 Mukherjee P, Faber AC, Shelton LM, Baek RC, Chiles TC, Seyfried TN: Thematic review series: sphingolipids. Ganglioside GM3 suppresses the proangiogenic effects of vascular endothelial growth factor and ganglioside GD1a. J Lipid Res 2008;49:929-938.

37 Jin J, Sison K, Li C, Tian R, Wnuk M, Sung HK, et al. Soluble FLT1 binds lipid microdomains in podocytes to control cell morphology and glomerular barrier function. Cell 2012;151:384-99.

38 Shimamura H, Terada Y, Okado T, Tanaka H, Inoshita S, Sasaki S: The PI3-kinase-Akt pathway promotes mesangial cell survival and inhibits apoptosis in vitro via NF-kappa B and Bad. J Am Soc Nephrol 2003;14:1427- 1434.

39 Zador IZ, Deshmukh GD, Kunkel R, Johnson K, Radin NS, Shayman JA: A role for glycosphingolipid accumulation in the renal hypertrophy of streptozotocin-induced diabetes mellitus. J Clin Invest 1993;91:797-803.

40 Novak A, Režić Mužinić N, Cikeš Čulić V, Božić J, Tičinović Kurir T, Ferhatović L, Puljak L, Markotić A: Renal distribution of ganglioside GM3 in rat models of types 1 and 2 diabetes. J Physiol Biochem 2013;69:727-735.

41 Singer SJ, Nicolson GL: The fluid mosaic model of the structure of cell membranes. Science 1972;175:720731.

42 Simons K, Toomre D: Lipid rafts and signal transduction. Nat Rev Mol Cell Biol 2000;1:31-39.

43 Vereb G, Szöllosi J, Matkó J, Nagy P, Farkas T, Vigh L, Mátyus L, Waldmann TA, Damjanovich S: Dynamic, yet structured: The cell membrane three decades after the Singer-Nicolson model. Proc Natl Acad Sci USA 2003;100:8053-8058.

44 Simons K, Ikonen E: Functional rafts in cell membranes. Nature 1997;387:569-572.

45 Liu L, Pilch PF: A critical role of cavin (polymerase I and transcript release factor) in caveolae formation and organization. J Biol Chem 2008;283:4314-4322.

46 Sowa G: Caveolae, caveolins, cavins, and endothelial cell function: new insights. Front Physiol 2012;2:120.

47 Regina Todeschini A, Hakomori SI: Functional role of glycosphingolipids and gangliosides in control of cell adhesion, motility, and growth, through glycosynaptic microdomains. Biochim Biophys Acta 2008;1780:421433.

48 Boggs JM, Gao W, Hirahara Y: Myelin glycosphingolipids, galactosylceramide and sulfatide, participate in carbohydrate-carbohydrate interactions between apposed membranes and may form glycosynapses between oligodendrocyte and/or myelin membranes. Biochim Biophys Acta 2008;1780:445-455.

49 Hakomori SI: Structure and function of glycosphingolipids and sphingolipids: recollections and future trends. Biochim Biophys Acta 2008;1780:325-346.

50 Albertoni Borghese MF, Majowicz MP, Ortiz MC, Passalacqua Mdel R, Sterin Speziale NB, Vidal NA: Expression and activity of SGLT2 in diabetes induced by streptozotocin: relationship with the lipid environment. Nephron Physiol 2009;112:p45-52. 


\section{Kidney \\ Blood Pressure Research}

\section{Kidney Blood Press Res 2015;40:306-314}

DOI: $10.1159 / 000368506$

Published online: May 30, 2015

(C) 2015 S. Karger AG, Basel

www.karger.com/kbr

Vukovic/Bozic/Markotic/Ljubicic/ Ticinovic Kurir: GM3 and Diabetic Nephropathy

51 Welker P, Böhlick A, Mutig K, Salanova M, Kahl T, Schlüter H, Blottner D, Ponce-Coria J, Gamba G, Bachmann $\mathrm{S}$ : Renal Na+-K+-Cl- cotransporter activity and vasopressin-induced trafficking are lipid raft dependent. Am J Physiol Renal Physiol 2008;295:F789-802.

52 Saito M, Sugiyama K: Gangliosides in rat kidney: composition, distribution, and developmental changes. Arch Biochem Biophys 2001;386:11-16.

53 Chen Y, Qin J, Chen ZW: Fluorescence-topographic NSOM directly visualizes peak-valley polarities of GM1/ GM3 rafts in cell membrane fluctuations. J Lipid Res 2008;49:2268-2275.

54 Kwak DH, Rho YI, Kwon OD, Ahan SH, Song JH, Choo YK, Kim SJ, Choi BK, Jung KY: Decreases of ganglioside GM3 in streptozotocin-induced diabetic glomeruli of rats. Life Sci 2003;72:1997-2006.

55 Andrews PM: Glomerular epithelial alterations resulting from sialic acid surface coat removal. Kidney Int 1979;15:376-385.

56 Jeansson M, Haraldsson B: Morphological and functional evidence for an important role of the endothelial cell glycocalyx in the glomerular barrier. Am J Physiol Renal Physiol 2006;290:F111-116.

57 Fridén V, Oveland E, Tenstad O, Ebefors K, Nyström J, Nilsson UA, Haraldsson B: The glomerular endothelial cell coat is essential for glomerular filtration. Kidney Int 2011;79:1322-1330.

58 Lennon R, Randles MJ, Humphries MJ: The importance of podocyte adhesion for a healthy glomerulus. Front Endocrinol (Lausanne) 2014;5:160.

59 Varki A, Freeze HH: Glycans in Acquired Human Diseases; in Varki A, Cummings RD, Esko JD, Freeze HH, Stanley P, Bertozzi CR, Hart GW, Etzler ME (eds): Essentials of Glycobiology. Cold Spring Harbor Laboratory Press Inc., Cold Spring Harbor, New York, Chapter 43, 2009.

60 Tomino Y: Pathogenesis and treatment of chronic kidney disease: a review of our recent basic and clinical data. Kidney Blood Press Res 2014;39:450-489.

61 Li D, Lu Z, Jia J, Zheng Z, Lin S: MiR-124 is related to podocytic adhesive capacity damage in STZ-induced uninephrectomized diabetic rats. Kidney Blood Press Res 2013;37:422-431.

62 Hakomori SI: The glycosynapse. Proc Natl Acad Sci U S A 2002;99:225-232.

63 Toyoda M, Najafian B, Kim Y, Caramori ML, Mauer M: Podocyte detachment and reduced glomerular capillary endothelial fenestration in human type 1 diabetic nephropathy. Diabetes 2007;56:2155-2160.

64 Nicolaou N, Margadant C, Kevelam SH, Lilien MR, Oosterveld MJ, Kreft M, van Eerde AM, Pfundt R, Terhal PA, van der Zwaag B, Nikkels PG, Sachs N, Goldschmeding R, Knoers NV, Renkema KY, Sonnenberg A: Gain of glycosylation in integrin alpha3 causes lung disease and nephrotic syndrome. J Clin Invest 2012;122:43754387. 